\title{
Penerapan sistem enterprise resource planning: dampak terhadap kinerja keuangan perusahaan
}

\author{
Cornelia Endra Kristianti ${ }^{1}$, Didi Achjari ${ }^{2}$ \\ Fakultas Ekonomika dan Bisnis, Universitas Gadjah Mada, Yogyakarta, Indonesia \\ e-mail: ${ }^{1}$ cornelia.endra.k@mail.ugm.ac.id; ${ }^{2}$ didi_a@ugm.ac.id
}

\section{A R T I K E L I N F O}

Article history:

Available online

Keywords:

Enterprise Resource Planning

(ERP), kinerja keuangan

perusahaan, sistem informasi

akuntansi, labor productivity (LP),

Return on Assets (ROA), Net

Profit Margin (NPM), Account

Receivable Turnover (ART), dan

inventory turnover (IT).

\section{A B S T R A C T}

This study aims to investigate the impact of implementation of Enterprise Resource Planning (ERP) system toward company's financial performance. The company's financial performance is measured by the ratio of labor productivity (LP), Return on Assets (ROA), Net Profit Margin (NPM), Account Receivable Turnover (ART), and Inventory Turnover (IT). Sample used in this study are 34 public listed companies that have implemented ERP system in the period of 20022013. Data were analyzed by comparing the company's financial ratios for 3 years before and after ERP implementation. The results show that productivity, receivables and inventory management are improved after ERP implementation. Unfortunately, the current research fail to show that there is an increase in company's profitability after the implementation.

\begin{abstract}
A B S T R A K
Penelitian ini bertujuan untuk mengetahui dampak penerapan sistem informasi khususnya Enterprise Resource Planning (ERP) terhadap peningkatan kinerja keuangan perusahaan. Kinerja keuangan perusahaan diukur berdasarkan rasio keuangan, yaitu rasio labor productivity (LP), Return on Assets (ROA), Net Profit Margin (NPM), Account Receivable Turnover (ART), dan inventory turnover (IT). Sampel yang digunakan adalah 34 perusahaan yang terdaftar di bursa efek yang telah mengimplementasikan sistem ERP dalam rentang tahun 2002-2013. Data dianalisis dengan membandingkan berbagai rasio diatas 3 tahun sebelum dan sesudah implementasi sistem ERP. Hasil penelitian menunjukkan bahwa terjadi peningkatan produktivitas serta perbaikan manajemen piutang dan persediaan setelah perusahaan mengimplementasikan ERP. Penelitian ini sayangnya tidak berhasil membuktikan adanya peningkatan profitabilitas setelah perusahaan mengimplementasikan ERP. Penelitian selanjutnya dapat diarahkan pada level implementasi ERP, karena perusahaan bisa saja latar belakangnya belum pernah menerapkan ERP.
\end{abstract}

\section{Pendahuluan}

Teknologi informasi berkaitan dengan proses dan aplikasi yang menciptakan metode baru untuk menyelesaikan permasalahan, menjalankan tugas-tugas, dan mengelola komunikasi (Ferrel et al. 2009). Penggunaan teknologi yang memadai dalam pengelolaan informasi sangat mendukung aktivitas operasional bisnis perusahaan. Hal ini dikarenakan informasi berperan penting dalam proses pembuatan keputusan. Semakin sedikit informasi tersedia, akan semakin tinggi resiko dari suatu keputusan (Ferrel et al. 2009).

Investasi perusahaan untuk bidang teknologi informasi terus mengalami pertumbuhan. Data dari Gartner ${ }^{1}$ menunjukkan bahwa pengeluaran perusahaan di bidang teknologi informasi secara global diprediksi tumbuh 2.7\%, atau sebesar $\$ 3.5$ triliun pada tahun 2017. Pada tahun 2018, pengeluaran teknologi informasi oleh perusahaan di Asia Tenggara diperkirakan sebesar $\$ 62$ milyar. Banyak perusahaan yang terus berupaya meningkatkan kompetensi dengan memanfaatkan teknologi informasi. Maka dari itu, penting bagi perusahaan untuk memahami bagaimana investasi teknologi informasi berkontribusi pada pencapaian tujuan bisnis. Santos et al. (1993), menyatakan bahwa dalam penilaian investasi di bidang teknologi informasi, hanya innovative technology, atau teknologi yang mampu mendukung perbaikan proses bisnis, yang diharapkan dapat

\footnotetext{
${ }^{1}$ Gartner adalah sebuah perusahaan riset teknologi informasi dan perusahaan penasihat Amerika Serikat. Gartner mengulas informasiinformasi terkini yang berkaitan dengan dunia teknologi informasi. Data pertumbuhan pengeluaran di bidang teknologi informasi diambil dari http://www.gartner.com/newsroom/id/3568917
} 
meningkatkan nilai dan kinerja perusahaan. Salah satu teknologi informasi yang dinilai inovatif oleh Hunton et al. (2003) adalah Enterprise Resource Planning (ERP). Hal tersebut dikarenakan ERP bisa menghasilkan peningkatan kualitas informasi, pengambilan keputusan dan kinerja perusahaan. Hal tersebut bisa tercapai karena ERP pada dasarnya adalah otomatisasi dan integrasi end-to-end proses bisnis di organisasi. Sistem ERP secara umum bisa terdiri dari beberapa modul, seperti modul keuangan, sumber daya manusia dan penggajian, order to cash, manufacture purchase to pay, manajemen proyek, customer relationship management, dan system tools (Romney dan Steinbart 2012)

Sistem ERP merupakan paket teknologi informasi bisnis yang kompleks, yang dalam proses implementasinya memakan biaya yang tidak sedikit. Salah satu contohnya adalah PT Angkasa Pura I yang menghabiskan biaya sebesar Rp 64 Miliar dalam proses implementasi ERP (Wedo 2013). Nilai investasi yang cukup tinggi ini tentu diikuti dengan harapan adanya dampak yang signifikan pada kinerja perusahaan. Kanellou dan Spathis (2013) meneliti dampak penerapan sistem ERP dari dimensi akuntansi. Hasil penelitian menunjukkan penerapan sistem ERP memberikan keuntungan pada beberapa dimensi akuntansi, yaitu teknologi informasi, operasional (waktu dan kos), organisasional, dan manajerial. Poston dan Grabski (2001) meneliti dampak penerapan sistem ERP pada kinerja perusahaan selama periode 3 tahun. Penelitian tersebut menunjukkan hasil adanya penurunan rasio jumlah karyawan terhadap penjualan yang signifikan selama 3 tahun dan ada pengurangan rasio cost of goods sold terhadap pendapatan di tahun ketiga.

Penelitian Hitt et al. (2002) menunjukkan dampak implementasi ERP terhadap kinerja perusahaan dilihat dari ukuran produktifitas berupa rasio-rasio dalam laporan keuangan. Hasil penelitian menunjukkan bahwa perusahaan yang melakukan implementasi ERP cenderung menghasilkan kinerja yang lebih tinggi pada berbagai metriks keuangan. Meskipun ada perlambatan pada kinerja dan produktifitas perusahaan sesaat setelah implementasi, pasar keuangan secara konsisten menghargai perusahaan yang mengadopsi ERP dengan penilaian pasar yang lebih tinggi. Hunton et al. (2003) juga melakukan penelitian mengenai pengaruh implementasi ERP terhadap kinerja perusahaan dengan cara membandingkan kinerja perusahaan yang menerapkan ERP dengan perusahaan yang tidak menerapkan ERP. Hasil penelitian tersebut menunjukkan bahwa return on assets (ROA), return on investment (ROI) dan assets turnover (ATO) perusahaan yang tidak menerapkan ERP secara signifikan lebih rendah dibandingkan dengan perusahaan yang menerapkan ERP pada tahun ketiga setelah implementasi ERP.

Penelitian mengenai dampak implementasi sistem ERP terhadap kinerja perusahaan di Indonesia telah banyak dilakukan. Hasil penelitian yang dilakukan oleh Lianto et al. (2009) menyatakan bahwa terjadi peningkatan secara signifikan rasio-rasio keuangan, yaitu inventory turnover, net profit margin, gross profit margin, operating margin, dan pre-tax margin, setelah perusahaan menerapkan sistem ERP. Namun hasil penelitian yang berbeda ditunjukkan oleh Kurniawati et al. (2015) yang menyatakan bahwa tidak terjadi hubungan langsung antara implementasi ERP dengan kinerja keuangan. Lebih lanjut penelitian tersebut menyatakan bahwa ERP dapat meningkatkan kapabilitas perusahaan. Hasil yang juga berbeda ditunjukkan oleh Achjari dan Wahyuningtyas (2014) melalui penelitiannya mengenai ekspektasi investor atas kinerja perusahaan terhadap pengumuman investasi teknologi informasi pada perusahaan sektor keuangan dan non keuangan. Hasil penelitian tersebut menyatakan bahwa investasi teknologi informasi yang dilakukan oleh perusahaan tidak memberikan sinyal positif untuk potensi peningkatan kekayaan perusahaan.

Berdasar pada hasil penelitian terdahulu di atas, penelitian ini dilakukan untuk mengetahui apakah terjadi peningkatan kinerja keuangan yang diukur dari rasio-rasio keuangan pada perusahaan-perusahaan di Indonesia sesudah menerapkan sistem ERP. Berbeda dengan Achjari dan Wahyuningtyas (2014) yang menggunakan pengukuran dampak implementasi ERP melalui perubahan harga saham di pasar modal, penelitian ini mengukur dampaknya melalui berbagai rasio keuangan yang ada di perusahaan.

\section{Tinjauan Pustaka dan Perumusan Hipotesis}

\section{Sistem Informasi Akuntansi}

Menurut Romney dan Steinbart (2012), sistem informasi akuntansi adalah sarana penyedia informasi dari aktivitas akuntansi. Ada 6 komponen sistem informasi akuntansi, yaitu manusia, prosedur dan instruksi, data, perangkat lunak, infrastruktur teknologi informasi, serta pengendalian internal dan ukuran keamanan. Mereka juga mengemukakan nilai tambah yang bisa diberikan oleh sistem informasi akuntansi kepada organisasi apabila dirancang dengan baik, nilai tambah tersebut adalah:

1. Meningkatkan kualitas dan mengurangi kos dari produk dan jasa

2. Meningkatkan efisiensi

3. Membagikan pengetahuan 
4. Meningkatkan efisiensi dan efektifitas dari rantai pasokan perusahaan

5. Meningkatkan struktur pengendalian internal

6. Meningkatkan proses pengambilan keputusan

\section{Enterprise Resource Planning}

Enterprise Resource Planning (ERP) adalah sebuah aplikasi dan database yang mengotomatisasi dan mengintegrasi pemrosesan informasi pada waktu yang riil dari sejumlah besar proses dan fungsi bisnis pada suatu organisasi (Anderson et al. 2011). ERP mengintegrasikan berbagai prosedur, aplikasi, dan departemen dalam suatu bisnis sekaligus berbagi satu basis data dan mendukung kerja perusahaan dengan real-time information (Kanellou dan Spathis 2013). Sistem perangkat lunak ERP memuat cakupan yang luas dari produk perangkat lunak yang mendukung operasi bisnis sehari-hari dan proses pengambilan keputusan (Hitt et al. 2002). ERP mengutamakan integrasi antar bagian dalam perusahaan sehingga informasi dapat digunakan atau diakses secara bersamaan. Sistem ERP terdiri dari beberapa modul, sehingga perusahaan dapat menerapkan sebagian atau seluruh modul sesuai kebutuhan mereka. Beberapa modul ERP menurut Romney dan Steinbart (2012):

1. Financial. Fungsi modul ini adalah untuk melakukan jurnal umum dan sistem pelaporan antara lain jurnal umum, piutang, aset tetap, penganggaran, manajemen kas, serta persiapan laporan manajerial dan laporan keuangan.

2. Human resources and payroll. Modul ini untuk mengelelola sumber daya manusia, penggajian, employee benefit, pelatihan, waktu dan kehadiran, benefits, dan laporan untuk pihak yang membutuhkan.

3. Order to cash (siklus pendapatan). Modul ini untuk melakukan entri pesanan penjualan, pengiriman, persediaan, penerimaan kas, dan perhitungan komisi.

4. Purchase to pay (siklus pengeluaran). Modul ini terkait dengan pembelian, penerimaan dan pemeriksaan persediaan, manajemen persediaan dan gudang, serta pengeluaran kas.

5. Manufacturing (siklus produksi). Modul ini bermanfaat untuk mengatur jadwal produksi, tagihan bahan baku, barang dalam proses, manajemen alur kerja, pengendalian kontrol, manajemen kos, serta proyek dan proses manufaktur.

6. Project management (costing). Modul ini untuk mengelola penagihan, waktu dan beban, unit kinerja, dan manajemen aktivitas.

7. Customer relationship management. Modul ini terkait dengan penjualan dan pemasaran, komisi, pelayanan, customer contact, dan call center support,

8. System tools. Modul ini adalah alat untuk membuat master file data, menentukan arus informasi, pengendalian akses, dan sebagainya.

\section{Analisis Rasio dalam Laporan Keuangan}

Sebuah rasio menggambarkan hubungan matematis antara satu kuantitas dan kuantitas lainnya (Kieso et al. 2011). Menurut Subramanyam (2014), rasio yang diinterpretasikan dengan tepat dapat mengidentifikasi area-area yang membutuhkan investigasi lebih lanjut. Kieso et al. (2011) mengklasifikasikan rasio menjadi 4 tipe yaitu; (1) Rasio likuiditas, yang mengukur kemampuan jangka pendek perusahaan untuk membayar kewajiban yang jatuh tempo; (2) Rasio aktivitas yang mengukur seberapa efektif perusahaan menggunakan asetnya; (3) Rasio profitabilitas yang mengukur tingkat kesuksesan atau kegagalan dari sebuah perusahaan atau divisi untuk suatu periode; (4) Coverage ratio yang mengukur tingkat perlindungan untuk investor dan kreditur jangka panjang.

Rasio keuangan yang digunakan dalam penelitian ini adalah rasio labor productivity (LP), return on assets (ROA), net profit margin (NPM), inventory turnover (IT), dan account receivable turnover (ART). Rasio labor productivity menggambarkan tingkat produktifitas karyawan dengan menghitung berapa pendapatan yang bisa dihasilkan oleh setiap karyawan. Return on assets (ROA) mengukur efektifitas manajemen secara keseluruhan dalam menghasilkan keuntungan dengan aset perusahaan yang tersedia (Gitman dan Zutter 2012). Rasio ROA yang semakin tinggi mengindikasikan efektifitas manajemen aset yang semakin tinggi pula. Rasio net profit margin menjelaskan proporsi laba bersih terhadap penjualan perusahaan. ROA dan NPM menggambarkan profitabilitas perusahaan. Rasio ART mengukur berapa kali perusahaan dapat mengumpulkan piutangnya selama satu periode (Kieso et al. 2011). Apabila pelanggan membayar dalam jangka waktu yang cepat, tagihan yang belum terbayar relatif akan menjadi kecil proporsinya dalam penjualan dan receivable turnover akan menjadi tinggi (Brealey et al. 2017). Rasio IT mengukur rata-rata jumlah waktu perusahaan dalam menjual persediaan barang dagangnya selama satu periode (Kieso et al. 2011). Rasio-rasio tersebut dipilih untuk mengetahui dampak penerapan ERP terhadap profitablitas (ROA dan NPM), aktivitas (IT dan ART) serta produktivitas (LP) perusahaan. 
Analisis laporan keuangan adalah aplikasi dari alat-alat dan teknik analisis untuk mencapai tujuan umum laporan keuangan dan data terkait sehingga bisa diperoleh estimasi dan kesimpulan yang bermanfaat dalam analisis bisnis (Subramanyam 2014). Analisis laporan keuangan mengurangi ketergantungan keputusan bisnis pada dugaan dan intuisi, atau dengan kata lain mengurangi ketidakpastian dari analisis bisnis. Analisis laporan keuangan menyediakan dasar yang sistematis dan efektif untuk analisis bisnis. Menurut Subramanyam (2014), ada lima kelompok alat analisis penting dalam analisis laporan keuangan, yaitu comparative financial statement analysis (analisis horizontal), common-size financial statement analysis (analisis vertikal), analisis rasio, analisis arus kas, dan valuasi. Analisis rasio adalah sarana yang paling banyak digunakan dalam analisis keuangan perusahaan. Subramanyam (2014) menyatakan bahwa analisis rasio dapat mengungkapkan hubungan penting dan dasar perbandingan dalam menemukan kondisi dan kecenderungan yang sulit dideteksi jika hanya memeriksa salah satu dari komponen yang membentuk rasio tersebut.

\section{Penelitian Terdahulu dan Pengembangan Hipotesis}

Dampak implementasi ERP dilihat dari berbagai rasio keuangan telah diteliti sebelumnya. Hitt et al. (2002) melakukan penelitian mengenai ERP yang membahas dampak bisnis yang didapatkan perusahaan dilihat dari ukuran produktifitas. Penelitian tersebut menggunakan beberapa rasio keuangan seperti, Return on Assets (ROA), profit margin, inventory turnover, dan account receivable turnover untuk mengukur produktifitas perusahaan.

Penerapan sistem Enterprise Resource Planning fokus pada proses integrasi dari berbagai bagian di perusahaan. ERP juga memungkinkan terjadinya berbagai otomatisasi kegiatan perusahaan (Tambovceva dan Tambovceva. 2013). Dengan penerapan sistem ERP, pekerjaan yang awalnya dilakukan secara manual, dapat dikerjakan oleh sistem. Hal ini dapat berdampak pada pengurangan jumlah karyawan. Tambovceva dan Tambovceva (2013) juga menyatakan bahwa salah satu dampak dari implementasi sistem ERP adalah peningkatan produktivitas. Poston dan Grabski (2001), meneliti pengaruh implementasi sistem ERP terhadap kinerja perusahaan dalam rentang waktu tiga tahun setelah penerapan sistem ERP. Hasil penelitian menunjukkan bahwa terjadi penurunan yang signifikan atas rasio jumlah karyawan terhadap pendapatan di ketiga tahun awal penerapan ERP. Berdasarkan uraian tersebut, disusunlah hipotesis penelitian sebagai berikut:

$\mathrm{H}_{1}$ : Rasio labor productivity sesudah implementasi ERP akan menjadi lebih tinggi dibanding sebelum implementasi ERP.

Return on Assets (ROA) dan return on sales atau net profit margin (NPM) telah digunakan untuk mengukur kinerja keuangan perusahaan. Menurut Hunton et al. (2003), ROA sebagai ukuran produktifitas perusahaan, menggabungkan profitabilitas dan efisiensi perusahaan, sehingga dapat menjadi indikator kinerja keseluruhan yang bermanfaat. =Penelitian tersebut juga menggunakan NPM sebagai rasio sekunder, yang mana juga merupakan ukuran tingkat profitabilitas perusahaan.

Hitt et al. (2002) juga menggunakan ROA dan NPM untuk membandingkan kinerja keuangan perusahaan sebelum, selama dan setelah menerapkan sistem ERP. Hasil penelitian tersebut menunjukkan bahwa secara konsisten, kinerja perusahaan terukur lebih baik setelah perusahaan mengimplementasi ERP. Penelitian juga memperlihatkan bahwa ada peningkatan yang substansial di hampir semua metrik selama adopsi, yang mana beberapa diantaranya biasanya menghilang dalam periode pasca-adopsi. Hal ini menunjukkan bahwa sebagian besar keuntungan yang sebelumnya diukur merupakan efek dari pelaksanaan ERP, bukan didorong oleh karakteristik perusahaan yang sudah ada. Penerapan sistem ERP diharapkan dapat meningkatkan profitabilitas yang diukur melalui ROA dan NPM. Berdasarkan uraian tersebut, maka disusunlah beberapa hipotesis sebagai berikut:

$\mathrm{H}_{2}$ : ROA perusahaan sesudah menerapkan sistem ERP akan lebih tinggi dibandingkan ROA perusahaan sebelum menerapkan sistem ERP.

$\mathrm{H}_{3}$ : NPM perusahaan sesudah menerapkan sistem ERP akan lebih tinggi dibandingkan NPM perusahaan sebelum menerapkan sistem ERP.

Integrasi merupakan konsep paling penting dalam penerapan sistem ERP. Sistem ERP memberikan beberapa nilai tambah bagi perusahaan, diantaranya adalah komunikasi yang lebih baik dan terintegrasi dengan customers dan suppliers yang diharapkan akan berdampak pada manajemen piutang dan hutang yang lebih baik pula. Penelitian yang dilakukan oleh Hitt et al. (2002) menunjukkan bahwa manajemen piutang perusahaan yang menerapkan sistem ERP lebih baik bila dibandingkan dengan perusahaan yang tidak menerapkan sistem ERP. Selain itu, perputaran piutang perusahaan yang menerapkan sistem ERP juga mengalami peningkatan setelah proses implementasi. 
Loh et al. (2006); Nicolaou (2004); dan Elragal dan Al-Serafi (2011) menyatakan bahwa alasan keuntungan yang diharapkan oleh perusahaan dari penerapan sistem ERP diantaranya adalah peningkatan integrasi informasi dan kualitas informasi yang lebih baik. Sistem ERP mampu mengintegrasikan data perusahaan diantaranya data konsumen atau pelanggan serta mampu meningkatkan pengolahan data dan kualitas informasi (Martono 2012). Integrasi serta pengolahan data dan informasi yang baik inilah yang akan mendukung proses manajemen piutang perusahaan. Misalnya pencatatan data pelanggan yang terintegrasi dapat mendukung proses penagihan piutang oleh perusahaan. Pengambilan keputusan seperti kebijakan piutang, volume penjualan kredit, dan kebijakan pengumpulan piutang juga akan lebih mudah dilakukan dengan adanya integrasi. Berdasarkan uraian tersebut, maka disusunlah hipotesis sebagai berikut:

$\mathrm{H}_{4}$ : Account receivable turnover perusahaan sesudah menerapkan sistem ERP akan lebih tinggi dibandingkan account receivable turnover perusahaan sebelum menerapkan sistem ERP.

Keuntungan penerapan ERP yang akan diperoleh perusahaan salah satunya adalah perbaikan manajemen persediaan. Matolcsy et al. (2005) mengemukakan bahwa sistem ERP mengintegrasi informasi dari departemen seperti penjualan dan pengadaan dengan sistem produksi yang berdampak pada perbaikan jadwal produksi. Hal tersebut menghindarkan perusahaan dari kondisi stock out dan mencegah adanya penimbunan persediaan. Selain itu dengan adanya integrasi, komunikasi antar departemen juga menjadi lebih mudah. Departemen penjualan dan pembelian bisa mendapatkan informasi data persediaan secara lebih cepat atau informasi real time. Gudang bisa mendapatkan informasi real time data penjualan sehingga mempercepat proses pendistribusian barang. Integrasi informasi diharapkan mampu membantu perusahaan dalam pengelolaan persediaan. Berdasarkan uraian tersebut, maka disusunlah hipotesis sebagai berikut:

$\mathrm{H}_{5}$ : Inventory turnover perusahaan sesudah menerapkan sistem ERP akan lebih tinggi dibandingkan inventory turnover perusahaan sebelum menerapkan sistem ERP.

\section{Metoda Penelitian}

\section{Data dan Sampel}

Penelitian ini menggunakan dua macam sumber data. Pertama, perusahaan publik yang terdaftar di Bursa Efek Indonesia yang telah menerapkan ERP. Informasi penerapan sistem ERP didapatkan dari pengungkapan informasi terkait implementasi sistem di dalam laporan tahunan perusahaan. Kedua, data keuangan dari laporan keuangan perusahaan terdaftar di bursa efek yang masuk kriteria sebagai sampel. Laporan keuangan diunduh dari website perusahaan terkait dan dari website Bursa Efek Indonesia di www.idx.co.id.

Sampel yang diambil dalam penelitian ini ditetapkan secara purposif dengan ketentuan sebagai berikut: (1) Sampel merupakan perusahaan selain bank yang terdaftar di Bursa Efek Indonesia dan telah mengimplementasikan sistem ERP dalam rentang tahun 2002-2013. Bank tidak dimasukkan dalam kriteria karena mempunyai rasio yang berbeda dibanding perusahaan di sektor lain. Tahun 2002-2013 digunakan karena ketersediaan data. (2) Terdapat data tahun perusahaan sampel mulai mengimplementasikan sistem ERP. (3) Perusahaan sampel mempunyai data laporan keuangan satu hingga tiga tahun sebelum menerapkan ERP dan data laporan keuangan satu hingga tiga tahun setelah implementasi sistem ERP. Berdasarkan kriteria di atas, jumlah sampel yang diperoleh adalah 34 perusahaan (lihat Tabel 1).

\section{Definisi dan Pengukuran Variabel}

Rasio keuangan yang digunakan dalam penelitian ini adalah rasio labor productivity (LP), return on assets (ROA), net profit margin (NPM), inventory turnover (IT) dan account receivable turnover (ART). Rumus dari masingmasing rasio pengukuran kinerja perusahaan:

1. Labor Productivity (LP)

$$
L P=\frac{\text { Revenue }}{\text { Total Employee }}
$$

2. Return on assets (ROA)

$$
R O A=\frac{\text { Net income available for common stockholders }}{\text { Total assets }}
$$

3. Net profit margin (NPM)

$$
N P M=\frac{\text { Net Income Available to Common Stockholders }}{\text { Net Sales }}
$$


4. Inventory turnover (IT)

$$
I T=\frac{\text { Cost of Goods Sold }}{\text { Average Inventory }}
$$

5. Account receivable turnover (ART)

$$
A R T=\frac{\text { Net sales }}{\text { Average trade receivables }}
$$

\begin{tabular}{|c|c|c|}
\hline No. & Nama Perusahaan & Tahun Implementasi \\
\hline 2 & Asahimas Flat Glass Tbk & 2003 \\
\hline 3 & Gajah Tunggal Tbk & 2005 \\
\hline 4 & Indocement Tunggal Prakarsa Tbk & 2006 \\
\hline 5 & PT Multi Bintang Indonesia Tbk & 2007 \\
\hline 6 & Astra Agro Lestari & 2007 \\
\hline 7 & PT Timah Tbk & 2009 \\
\hline 8 & PT Humpuss Intermoda Transportasi Tbk & 2009 \\
\hline 9 & PT Indo Tambangraya Megah & 2009 \\
\hline 10 & PT Bukit Asam Tbk & 2009 \\
\hline 11 & PT Sierad Produce Tbk & 2009 \\
\hline 12 & PT Bumi Resources Tbk & 2009 \\
\hline 13 & Unilever & 2009 \\
\hline 14 & Siantar top & 2009 \\
\hline 15 & PT Astra Otopart Tbk & 2010 \\
\hline 16 & Krakatau Steel & 2010 \\
\hline 17 & PT Merck Tbk & 2010 \\
\hline 18 & PT Perusahaan Gas Negara Tbk & 2010 \\
\hline 19 & Champion Pacific & 2010 \\
\hline 20 & Semen Indonesia & 2010 \\
\hline 21 & PT Polychem Indonesia Tbk & 2011 \\
\hline 22 & PT Tiga Pilar Sejahtera Food Tbk & 2011 \\
\hline 23 & PT Apexindo Pratama Duta Tbk & 2011 \\
\hline 24 & PT Pelat Timah Nusantara Tbk & 2011 \\
\hline 25 & PT Vale Indonesia Tbk & 2011 \\
\hline 26 & PT Kedawung Setia Industrial Tbk & 2011 \\
\hline 27 & PT Fajar Surya Wisesa Tbk & 2012 \\
\hline 28 & PT Tira Austenite Tbk & 2012 \\
\hline 29 & JAPFA Comfeed Indonesia Tbk & 2012 \\
\hline 30 & PP London Sumatra Indonesia Tbk & 2012 \\
\hline 31 & PT Gema Grahasarana & 2012 \\
\hline 32 & Kimia Farma (Persero) Tbk & 2012 \\
\hline 33 & Wismilak Inti Makmur Tbk & 2013 \\
\hline 34 & Lautan Luas Tbk & 2013 \\
\hline
\end{tabular}

Tabel 1. Daftar Perusahaan Sampel yang Mengimplementasi Sistem ERP

Sumber: data yang diolah

\section{Metoda Analisis Data dan Pengujian Hipotesis}

Dalam analisis data, peneliti terlebih dahulu melakukan penghitungan rasio-rasio keuangan dari setiap perusahaan sampel yang didasarkan pada data di dalam laporan keuangan perusahaan sampel. Kinerja dibagi menjadi dua periode waktu, yaitu periode sebelum ( $t-1$ sampai $t-3)$ dan periode sesudah $(t+1$ sampai $t+3)$ implementasi sistem ERP (Hunton et al. 2003). Penentuan periode ini dilakukan juga berdasarkan pernyataan Gattiker dan Goodhue (2005) dan Matolcsy et al. (2005) yang menyebutkan bahwa keuntungan dari implementasi ERP mulai muncul setelah 2 tahun atau lebih. Rasio yang dihitung tiap tahunnya akan dirata-rata kemudian dibandingkan antara periode sebelum dan sesudah implementasi ERP.

Selanjutnya pengujian normalitas data dilakukan untuk mengetahui apakah data terdistribusi secara normal atau tidak. Pengujian dilakukan pada hasil penghitungan rasio-rasio keuangan tiap perusahaan sebelum dan sesudah implementasi ERP menggunakan metode Kolmogorov-Smirnov test. Agar residual memiliki distribusi normal, variabel residu harus memiliki asymptot significance di atas tingkat signifikan sebesar 0.05 
(probabilitas $>0,05$ ). Apabila data terdistribusi secara normal, maka pengujian hipotesis penelitian akan dilakukan dengan menggunakan metode pengujian-t dua sampel berhubungan parametrik (parametrik paired-sample $t$ test). Ha diterima apabila $t$ hitung lebih besar daripada $t$ tabel atau jika nilai asymtot significance (2-tailed) yang diperoleh $<0,01,<0,05$ atau $<0,1$. Apabila data tidak berdistribusi normal, maka pengujian hipotesis penelitian dilakukan dengan pengujian statistik non parametrik dengan uji Wilcoxon Signed Rank Test dengan kriteria berikut ini: (1) Nilai Asymp. Sig. lebih kecil dari 0.05 berarti hipotesis alternatif diterima, (2) Nilai Asymp. Sig. lebih besar dari 0.05 berarti hipotesis alternatif ditolak.

\section{Hasil dan Pembahasan}

\section{Statistik Deskriptif}

Fenomena atau karakteristik dari suatu data dalam penelitian digambarkan melalui statistik deskriptif (Hartono 2017). Statistik deskriptif digunakan untuk memperlihatkan bagaimana karakteristik dari distribusi data yang diuji. Dalam penelitian ini, perbandingan hasil statistik deskriptif dilakukan antara rata-raata rasio keuangan sebelum implementasi ERP ( $\mathrm{t}-1$ hingga $\mathrm{t}-3$ ) dengan rata-rata rasio keuangan setelah implementasi ERP ( $t+1$ hingga $t+3)$.

Tabel 2: Statistik Deskriptif Rasio Keuangan Sebelum dan Sesudah Implementasi ERP

\begin{tabular}{llrrrr}
\hline \multicolumn{1}{c}{ Variabel } & Kondisi & Mean & Standar Deviasi & Min. & Maks. \\
\hline \multirow{2}{*}{ LP } & Sebelum & 1549,6000 & 1493,16173 & 83,94 & 6344,76 \\
& Sesudah & 2302,5806 & 2543,41409 & 288,74 & 14231,68 \\
\multirow{2}{*}{ ROA } & Sebelum & 10,7347 & 8,95129 & $-1,73$ & 37,00 \\
& Sesudah & 10,2947 & 13,04448 & $-18,04$ & 48,37 \\
\multirow{2}{*}{ NPM } & Sebelum & 11,0191 & 8,06073 & $-1,30$ & 29,07 \\
& Sesudah & 10,1397 & 10,39832 & $-7,59$ & 33,62 \\
ART & Sebelum & 11,1647 & 8,64360 & 2,36 & 41,78 \\
& Sesudah & 13,3850 & 10,71110 & 4,41 & 63,36 \\
IT & Sebelum & 8,2518 & 9,97355 & 1,55 & 49,20 \\
& Sesudah & 9,4679 & 11,38211 & 2,07 & 59,08 \\
\hline
\end{tabular}

Pada Tabel 2 terlihat bahwa rata-rata rasio ROA dan NPM setelah implementasi ERP tidak menunjukkan nilai yang lebih tinggi dibandingkan dengan rata-rata sebelum implementasi. Pada periode sebelum implementasi ERP, rata-rata ROA sebesar 10,7347, sedangkan pada periode setelah implementasi ERP, rata-rata ROA menjadi 1,2947. Rata-rata NPM sebelum implementasi ERP adalah 11,0191. Setelah implementasi ERP, rata-rata NPM menjadi 10,1397. ROA dan NPM menggambarkan profitabilitas perusahaan.

Rasio-rasio yang lain, yaitu LP, ART, dan IT, menunjukkan kinerja yang lebih baik bila dibandingkan antara sebelum dan setelah implementasi ERP. Rata-rata rasio IT dan ART sebelum implementasi ERP adalah 8,2518 dan 11,1647. Setelah implementasi ERP, rata-rata rasio IT dan ART meningkat menjadi 9,4679 dan 13,3850. Selain itu juga terdapat peningkatan rasio LP setelah implementasi ERP, dari 1549,6 menjadi 2302.

\section{Uji Normalitas Data}

Hasil pengujian normalitas di Tabel 3 menunjukkan bahwa tidak semua data terdistribusi secara normal. Rasio IT dan ART memiliki nilai asymp. sig. kurang dari 0,05 menunjukkan bahwa data tidak berdistribusi normal. Maka dari itu, pengujian hipotesis dilakukan dengan uji non parametrik Wilcoxon Signed Rank dengan tingkat signifikansi $5 \%$.

Tabel 3: Nilai Asymp. Sig. Untuk Setiap Rasio

\begin{tabular}{lcc}
\hline \multirow{2}{*}{ Variabel } & \multicolumn{2}{c}{ Asymp. Sig. } \\
\cline { 2 - 3 } & Sebelum Implementasi & Sesudah Implementasi \\
\hline LP &, 148 &, 088 \\
ROA &, 716 &, 192 \\
NPM &, 667 &, 440 \\
ART &, 034 &, 055 \\
IT &, 001 &, 011 \\
\hline
\end{tabular}




\section{Hasil Pengujian Hipotesis}

Hasil dari uji hipotesis dengan menggunakan uji non parametrik Wilcoxon Signed Rank ditunjukkan di Tabel 4.

Tabel 4: Hasil Uji Beda Rasio Keuangan Sebelum dan Sesudah Implementasi ERP

\begin{tabular}{|c|c|c|c|c|}
\hline \multirow[b]{2}{*}{ Hipotesis } & \multirow[b]{2}{*}{ Rasio } & \multicolumn{2}{|c|}{ Hasil } & \multirow[b]{2}{*}{ Kesimpulan } \\
\hline & & Z & $\begin{array}{l}\text { Asymp. Sig. } \\
\text { (2-tailed) }\end{array}$ & \\
\hline $\mathrm{H}_{1}$ & LP & $-4,334$ & ,000 & $\mathrm{H}_{1}$ diterima \\
\hline $\mathrm{H}_{2}$ & ROA &,- 350 & ,726 & $\mathrm{H}_{2}$ ditolak \\
\hline $\mathrm{H}_{3}$ & NPM &,- 316 & ,752 & $\mathrm{H}_{3}$ ditolak \\
\hline $\mathrm{H}_{4}$ & ART & $-3,154$ & ,002 & $\mathrm{H}_{4}$ diterima \\
\hline $\mathrm{H}_{5}$ & IT & -2.394 & ,017 & $\mathrm{H}_{5}$ diterima \\
\hline
\end{tabular}

\section{Perbandingan Rasio Labor Productivity Sebelum dan Setelah Implementasi ERP}

Hasil uji beda menunjukkan bahwa terdapat perbedaan yang signifikan antara rasio labor productivity sebelum dan setelah implementasi ERP. Hal tersebut ditunjukkan oleh nilai asymp. sig. yang lebih kecil dari 0,05 yaitu 0,000. Hasil ini menunjukkan bahwa peningkatan rata-rata rasio labor productivity pada statistik deskriptif merupakan peningkatan yang signifikan. Hal tersebut berarti hipotesis alternatif pertama $\left(\mathrm{H}_{1}\right)$ dalam penelitian ini diterima dan didukung oleh data penelitian. Hasil ini sejalan dengan hasil penelitian yang dilakukan oleh Poston dan Grabski (2001) dan Hayuningtyas (2008) yang menyatakan bahwa implementasi ERP akan berdampak pada peningkatan produktifitas tenaga kerja yang diukur melalui rasio labor productivity. Setelah implementasi sistem ERP, banyak proses yang mulanya dikerjakan secara manual, dapat dilakukan secara otomatis. Maka dari itu, kebutuhan perusahaan akan tenaga kerja akan berkurang, dengan tingkat pendapatan yang sama atau lebih tinggi. Dengan demikian, rasio labor productivity dapat mengalami peningkatan. Rata-rata rasio yang mengalami peningkatan ini menunjukkan bahwa jumlah pendapatan yang dihasilkan oleh tiap karyawan. Hal ini berarti produktivitas perusahaan meningkat setelah menerapkan sistem ERP.

\section{Perbandingan Rasio Return on Assets dan Net Profit Margin Sebelum dan Setelah Implementasi ERP}

Hasil penelitian memperlihatkan bahwa tidak ada perbedaan yang signifikan pada rasio Return on Assets dan Net Profit Margin setelah perusahaan menerapkan sistem ERP. Hal ini ditunjukkan oleh nilai asymp. sig. ROA dan NPM yang sebesar 0,726 dan 0,752. Keduanya lebih besar dari 0,05. Selain itu, rata-rata rasio dalam statistik deskriptif juga tidak menunjukkan adanya peningkatan. Maka hipotesis alternatif kedua dan ketiga $\left(\mathrm{H}_{2}\right.$ dan $\left.\mathrm{H}_{3}\right)$ ditolak. Hal ini sejalan dengan penelitian Hunton et al. (2003) yang menyatakan bahwa tidak terjadi perbedaan rasio ROA dan NPM yang signifikan antara periode sebelum dan sesudah perusahaan menerapkan sistem ERP. Hasil ini juga sejalan dengan penelitian yang dilakukan oleh Kurniawati et al. (2015) yang menghasilkan pernyataan bahwa implementasi ERP tidak berpengaruh terhadap kinerja keuangan. Dalam penelitian tersebut, kinerja keuangan diukur oleh tiga rasio, yaitu Return on Equity, Return on Asset, dan Net Profit Margin. Dengan demikian didapatkan hasil bahwa implementasi ERP tidak mempengaruhi profitabilitas perusahaan secara langsung.

\section{Perbandingan Rasio Account Receivable Turnover dan Inventory Turnover Sebelum dan Setelah Implementasi ERP}

Hasil uji beda memperlihatkan bahwa terdapat perbedaan rata-rata rasio account receivable turnover dan inventory turnover yang signifikan antara rasio sebelum dengan rasio setelah implementasi ERP. Hal ini ditunjukkan oleh nilai asymp. sig. yang lebih kecil dari 0,05 yaitu 0,02, dan 017 untuk kedua rasio tersebut. Hasil statistik deskriptif juga mendukung hipotesis, yang mana menunjukkan adanya peningkatan rata-rata rasio account receivable turnover dan inventory turnover setelah implementasi ERP. Dengan demikian, hipotesis keempat dan kelima $\left(\mathrm{H}_{4}\right.$ dan $\left.\mathrm{H}_{5}\right)$ diterima.

Hasil ini sejalan dengan penelitian yang dilakukan oleh Hayuningtyas (2008) dan Hitt et al. (2002) yang menunjukkan hasil adanya peningkatan signifikan pada kedua rasio tersebut setelah implementasi ERP. Peningkatan rata-rata rasio account receivable turnover setelah implementasi ERP juga sejalan dengan hasil penelitian yang dilakukan oleh Lianto et al. (2009). Sistem ERP menyediakan integrasi informasi antar departemen dalam perusahaan, termasuk informasi mengenai piutang, hutang, dan persediaan. Fungsi-fungsi yang terdapat dalam proses procurement, pembelian, produksi, penjualan, dan manajemen persediaan juga terintegrasi oleh adanya sistem ERP. Dengan integrasi tersebut, perusahaan bisa menghasilkan informasi atau 
keputusan-keputusan yang dibutuhkan dengan lebih cepat. Hal ini akan berdampak pula pada hubungan yang lebih baik antara perusahaan dengan pelanggan.

Rata-rata rasio account receivable turnover dan inventory turnover yang mengalami peningkatan menunjukkan adanya manajemen yang lebih baik terhadap piutang dan persediaan perusahaan. Rasio account receivable turnover yang lebih tinggi menunjukkan bahwa dalam waktu satu tahun perusahaan dapat mengumpulkan piutang dalam frekuensi yang lebih tinggi. Hal tersebut akan mengurangi jumlah piutang yang tak tertagih sehingga arus kas perusahaan akan menjadi lebih lancar. Integrasi dalam sistem ERP juga berdampak pada pengelolaan persediaan yang lebih baik yang ditunjukkan dengan rasio perputaran yang lebih tinggi. Pengelolaan persediaan yang lebih baik diharapkan dapat mengurangi kos penyimpanan persediaan.

Dari berbagai penjelasan di atas dapat diketahui bahwa implementasi sistem ERP tidak terbukti secara langsung berpengaruh pada peningkatan profitabilitas perusahaan. Hal tersebut diduga terjadi karena adanya faktor-faktor lain yang mempengaruhi, seperti kondisi pasar, fluktuasi harga, atau peningkatan biaya-biaya. Hal ini sejalan dengan penelitian yang dilakukan oleh Achjari dan Wahyuningtyas (2014) yang menyatakan bahwa investasi teknologi informasi yang dilakukan oleh perusahaan tidak berpengaruh pada profitabilitas yang digambarkan melalui sinyal positif untuk potensi peningkatan kekayaan perusahaan. Namun demikian, implementasi ERP tetap memiliki pengaruh positif untuk perusahaan dalam upaya meningkatkan produktivitas tenaga kerja dan perbaikan pengelolaan aset, yaitu persediaan dan piutang, serta pengelolaan hutang. Dalam jangka waktu yang lebih panjang, diharapkan peningkatan dan perbaikan tersebut akan berdampak pada peningkatan profitabilitas.

Perusahaan bisa mendapatkan manfaat-manfaat lain dari implementasi ERP. Penelitian yang dilakukan oleh Kuo (2014) menyatakan bahwa setelah implementasi ERP, perusahaan mendapatkan dampak positif tak berwujud (intangible) pada reputasi, kualitas keputusan, produktifitas, dan kualitas produk. Hasil penelitian lain yang dilakukan oleh Kurniawati et al. (2015) menyatakan bahwa implementasi ERP tidak secara langsung meningkatkan kinerja keuangan, namun dapat meningkatkan kapabilitas perusahaan yang selanjutnya akan mempengaruhi kinerja keuangan perusahaan.

\section{Simpulan}

Berdasarkan analisis data dan pembahasan di atas, hasil penelitian ini adalah sebagai berikut. Pertama, terdapat perbedaan rata-rata rasio labor productivity, account receivable turnover, dan inventory turnover yang signifikan pada periode sebelum dan setelah implementasi sistem ERP. Hal ini disebabkan karena adanya integrasi data dan sistem perusahaan yang menerapkan ERP. Integrasi tersebut berdampak pada meningkatnya produktivitas karyawan serta perbaikan manajemen piutang dan persediaan. Selanjutnya, hasil analisis data menunjukkan bahwa tidak terdapat perbedaan rata-rata rasio Return on Asset dan Net Profit Margin pada periode sebelum dan setelah implementasi sistem ERP. Rasio-rasio tersebut menggambarkan profitabilitas perusahaan. Hal ini berarti implementasi ERP tidak terbukti berdampak langsung pada peningkatan profitabilitas perusahaan.

Penelitian ini memiliki beberapa keterbatasan yang mana perlu kehati-hatian dalam melakukan generalisasi dan interpretasinya. Pertama, jumlah sampel penelitian terbatas karena perusahaan yang diteliti hanyalah perusahaan yang mengungkapkan implementasi ERP pada laporan keuangannya. Ada potensi bahwa perusahaan tidak mengungkapkan implementasi ERP secara memadai karena berbagai alasan. Kemungkinannya antara lain, perusahaan mengungkapkannya dengan nama yang lebih spesifik atau nama software tertentu yang sebenarnya termasuk kategori ERP. Kedua, penelitian ini tidak memperhatikan faktor-faktor lain yang dapat mempengaruhi perubahan rasio-rasio keuangan yang diukur. Ketiga, dalam penelitian ini, perusahaan tidak dibedakan berdasarkan klasifikasi dari sistem ERP yang diterapkan oleh masing-masing perusahaan. ERP yang diterapkan bisa bervariasi misalnya general ledger, logistic atau human resource, dengan potensi dampak yang berbeda-beda. Keempat, penelitian ini tidak memperhatikan industry effect dan size effect untuk membedakan perusahaan-perusahaan yang diteliti. Dalam penelitian sistem informasi sebelumnya, para peneliti menemukan pengaruh dari jenis industri dan skala perusahaan terhadap berbagai aspek implementasi sistem informasi (Santos et al. 1993).

Penelitian selanjutnya dapat menggunakan atau mencari data dari vendor ERP di Indonesia sehingga bisa didapatkan jumlah sampel yang lebih banyak. Penelitian selanjutnya juga dapat menggunakan ukuran kinerja keuangan perusahaan yang lain untuk mendapatkan gambaran mengenai kinerja perusahaan. Selanjutnya, Santos et al. (1993) menyatakan bahwa investasi teknologi informasi bisa memiliki dampak yang berbeda pada perusahaan yang bergerak di industri keuangan dan non keuangan. Maka, penelitian selanjutnya disarankan dapat membandingkan dampak implementasi ERP pada kinerja keuangan perusahaan yang bergerak di industri keuangan dan industri non keuangan. Akhirnya, penelitian lebih lanjut juga bisa diarahkan pada level implementasi ERP, karena perusahaan bisa saja latar belakangnya belum pernah menerapkan ERP. Dengan 
demikian implementasi ERP adalah hal yang sama sekali baru. Kemungkinan lain adalah peningkatan lingkup dari implementasi ERP sebelumnya. Perbedaan kondisi latar belakang implementasi ERP sebelumnya ini akan menarik untuk diteliti lebih lanjut.

\section{Daftar Referensi}

Achjari, D., dan A. E. Wahyuningtyas. 2014. Information technology investment announcements and firms' value: the case of Indonesian firms in the financial and non-financial sectors. Asian Journal of Business and Accounting 7 (2): 95-116.

Anderson, M., R. D. Banker, N. M. Menon, dan J. A. Romero. 2011. Implementing enterprise resource planning systems: organizational performance and the duration of the implementation. Information Technology and Management 12 (3): 197-212.

Brealey, R., S. Myers, dan F. Allen. 2017. Principles of corporate finance. Edisi ke-12. McGraw-Hill Education.

Elragal, A. A., dan A. M. Al-Serafi. 2011. The effect of ERP system implementation on business performance: an exploratory case-study. Communications of the IBIMA, 1-20.

Ferrel, O. C., G. A. Hirt, dan L. Ferrel. 2009. Business: a changing world. Edisi ke-7. New York: McGrawHill//rwin.

Gattiker, T. F., dan D. Goodhue. 2005. What happens after ERP implementation: understanding the impact of interdependence and differentiation on plant-level outcomes. MIS Quarterly 29 (3): 559-585.

Gitman, L. J., dan C. J. Zutter. 2012. Principles of managerial finance. Edisi ke-13. Harlow: Pearson Education Limited.

Hartono, J. 2017. Metodologi penelitian bisnis: salah kaprah dan pengalaman-pengalaman. Edisi ke-6. Yogyakarta: BPFE.

Hayuningtyas, V. K. 2008. Analisis kinerja perusahaan sebelum dan sesudah penerepan sistem enterprise resource planning (ERP) dengan value chain method. Universitas Gadjah Mada, Yogyakarta.

Hitt, L. M., D. J. Wu, dan X. Zhou. 2002. Investment in enterprise resource planning: business impact and productivity measures. Journal of Management Information Systems 19 (1): 71-98.

Hunton, J., B. Lippincott, dan J. Reck. 2003. Enterprise resource planning systems: comparing firm performance of adopters and nonadopters. International Journal of Accounting Information Systems 4 (1): 165-184.

Kanellou, A., dan C. Spathis. 2013. Accounting benefits and satisfaction in an ERP environment. International Journal of Accounting Information Systems 14: 209-34.

Kieso, D. E., J. J. Weygandt, dan T. D. Warfield. 2011. Intermediate accounting. IFRS edition. Edisi ke-2. John Wiley \& Sons, Inc.

Kuo, C. 2014. Effect of enterprise resource planning information system on business performance: an empirical case of Taiwan. Journal of Applied Finance \& Banking 4 (20): 1-19.

Kurniawati, M., I. K. Gunarta, dan I. Baihaqi. 2015. Dampak implementasi enterprise resource planning (ERP) pada kinerja keuangan: pendekatan resource based view. Seminar Nasional Manajemen Teknologi XXIII.

Lianto., Z. J. H. Tarigan, dan S. R. Basana. 2009. Enterprise resource planning system usage impacts towards financial performance, evidence from Indonesian stock exchange. The 4th International Conference on Business and Management Research. 22-24 November.

Loh, T., S. Koh, dan M. Simpson. 2006. An investigation of the value of becoming an extended enterprise. International Journal of Integrated Manufacturing 19 (1): 49-58.

Martono, A. 2012. E-business ERP (enterprise resources planning) untuk kompetisi bisnis. Rekayasa Teknologi 3: $1-9$.

Matolcsy, Z.P., P. Booth, dan B. Wieder. 2005. Economic benefits of enterprise resource planning systems: some empirical evidence. Accounting and Finance 45 (3): 439-56.

Nicolaou, A. 2004. Firm performance effects in relation to the implementation and use of enterprise resource 
planning systems. Journal of Information Systems 18 (2): 79-105.

Poston, R., dan S. Grabski. 2001. Financial impacts of enterprise resource planning implementations. International Journal of Accounting Information System 2 (4): 271-94.

Romney, M. B., dan P. J. Steinbart. 2012. Accounting information systems. Harlow: Pearson Education.

Santos, B. L. D., K. Peffers, dan D.C. Mauer. 1993. The impact of information technology investment announcements on the market value of the firm. Information Systems Research 4 (2): 1-23.

Subramanyam, K. R. 2014. Financial statement analysis. Edisi ke-11. New York: McGraw-Hill Education.

Tambovceva, A., dan T. Tambovceva. 2013. ERP system implementation: benefits and economic. International Conference on Systems, Control, Signal Processing and Informatics, 215-221.

Wedo, H. F. N. 2013. Angkasa pura I terapkan sistem ERP senilai Rp 64 miliar. Edisi 3 Januari. Diakses pada 5 Maret 2017, dari http://industri.bisnis.com/read/20130103/98/121088/angkasa-pura-i-terapkan-sistemerp-senilai-rp64-miliar. 